\title{
SISMTEM INFORMASI WARUNG KULINER
}

\author{
Muhammad Rizky Ariawan, Gunawan Ariyanto \\ Program Studi Informatika Universitas Muhammadiyah Surakarta (UMS) \\ Surakarta, Indonesia.rizkyarwn@gmail.com, Ga154@ums.ac.id
}

Warung Kuliner di Kota besar Indonesia saat ini masih banyak yang belum menggunakan Sistem Informasi untuk bertransaksi. Sehingga sering dijumpai masalah ketika melakukan transaksi, misalnya ketika pelanggan melakukan pembayaran dan kasir melakukan proses transaksi secara manual atau dengan menggunakan media konvensional. Tersedianya Aplikasi ini untuk mempermudah dan lebih efektif apabila digunakan, karena tidak perlu mencatat secara manual ketika bertransaksi dengan pelanggan serta memberikan informasi secara cepat, tepat, dan akurat. Manfaat lainnya yaitu pelanggan mengetahui secara langsung dari keseluruhan detail transaksi yang dilakukan. Artikel ini membahas perancangan Aplikasi berbasis web dengan Metode Waterfall yang dibangun menggunakan program Python Django. Hasil dari aplikasi ini mencakup pengolahan data produk, pengolahan data pesanan dan transaksi, grafik hasil transaksi, serta cetak nota hasil transaksi dengan format PDF.

Kata Kunci : Kasir, Kuliner, Sistem Informasi, Warung.

\section{PENDAHULUAN}

Perkembangan teknologi di zaman sekarang sangat pesat, menjadikan teknologi informasi suatu hal yang sangat penting dalam kebutuhan sehari-hari. Teknologi Informasi membantu untuk memenuhi kebutuhan hidup seperti adanya fasilitas untuk mengolah informasi dan menyediakan berbagai informasi yang mencakup di beberapa bidang yaitu dalam bidang pendidikan, bidang manajemen dan bidang bisnis. Bidang manajemen memberikan informasi barang dan jasa. Pemanfaatan sistem informasi ini untuk membantu dalam pengelolaan data yang ada, dimana data yang diolah digunakan untuk menganalisa dan menghitung data. Sistem informasi yang baik sangat berpengaruh dalam kinerja yang efektif dan efisien. Sistem informasi warung kuliner ini diterapkan sebagai pengganti dalam pengolahan konvensional yang saat ini masih digunakan, dan membantu kinerja pegawai secara cepat dan mudah. [1]

Warung Kuliner saat ini banyak di cari kalangan masyarakat terutama pengunjung luar kota, hal ini sangat berdampak bagi perkembangan di suatu daerah. Salah satu nilai penting dari suatu aplikasi warung kuliner adalah mengembangkan teknologi dari zaman ke zaman, memberikan kenyamanan bagi pelanggan serta mempermudah kinerja dalam melayani dan melakukan transaksional.

Namun beberapa warung kuliner di kota besar wilayah Indonesia sementara ini masih banyak yang belum menggunakan aplikasi kasir. Sering kali terjadi kesalahan ketika bertransaksi secara langsung, misalnya saat pemesanan menu makanan dan pencatatan penjualan yang masih menggunakan cara manual pada media konvensional. [2] Sistem Informasi Warung Kuliner harus dapat memberikan hasil maksimal dan keterangan yang lengkap untuk transaksional pada pelanggan.

Aplikasi dengan penerapan multiplatform sangat dibutuhkan saat ini melihat banyaknya perangkat yang semakin berkembang dan dibutuhkan oleh masyarakat. [3] Salah satu contohnya adalah kebutuhan Sistem Informasi Warung Kuliner yang effisien, oleh sebab itu diperlukan sebuah perancangan aplikasi dengan spesifikasi yang baik yaitu menampilkan informasi menu makanan, minuman dan komponen lain diantarannya pencarian, kategori menu dan pengelolaan laporan hasil transaksi secara terperinci.

Aplikasi ini dibuat menggunakan bahasa pemrograman Python Django. Dibuatnya 
Aplikasi Sistem Informasi Warung Kuliner ini dapat membantu dan memudahkan pegawai dalam bertransaksi serta memberikan pelayanan yang lebih baik bagi konsumen.

Menurut survei yang dilakukan oleh peneliti melalui lokasi langsung dan situs-situs online (github), ada beberapa warung yang sudah menggunakannya namun aplikasi tersebut berbayar. Terdapat beberapa fitur seperti kategori dan produk, price and quantity, serta laporan. Sedangkan survei secara online (github) aplikasi kasir ini masih sangat sederhana baik dalam fitur maupun tampilan.

Menurut survei yang dilakukan oleh peneliti, pada warung SBC Spesial ca kangkung mempunyai beberapa permasalahan yaitu pada aplikasi kasir yang sering mengalami hang maupun error. Adanya permasalahan tersebut tentunya terdapat cara untuk mengatasinya yaitu dengan cara menghentikan aplikasi secara paksa atau dengan menghidupkan ulang komputer. Sedangkan pada warung SFA Steak \& Resto, aplikasi kasir sering mengalami trouble pada server. Misalnya, ketika listrik padam dapat mengakibatkan proses transaksi tidak berjalan lancar karena sistem terhubung dengan jaringan pusat. Permasalahan tersebut ditangani oleh pihak SFA dengan melakukan transaksi dengan menggunakan media konvensional.

Pentingnya aplikasi warung kuliner ini adalah sebagai wadah atau jalan alternative yang sangat dibutuhkan, sehingga dapat mempermudah proses transaksi sebuah warung kuliner. Sistem tersebut dibagikan secara gratis yang dapat di Download melalui Github https://github.com/rizkyarwn/ projectkasir.

\section{METODE}

Aplikasi Warung Kuliner ini dikembangkan menggunakan metode waterfall. Metode waterfall merupakan pendekatan yang sistematis yang berurutan pada pengembangan perangkat lunak dengan spesifikasi kebutuhan yang memadai. Metode waterfall ditunjukkan pada Gambar 1.

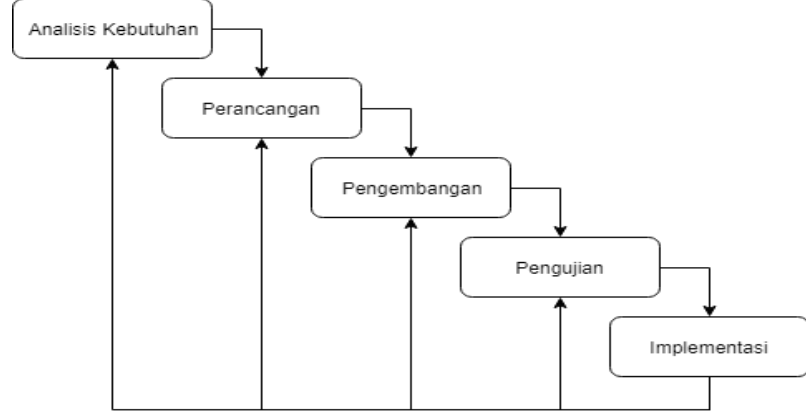

Gambar 1. Metode Waterfall

a. Analisis Kebutuhan

Tahap pengembangan sistem ini memerlukan komunikasi dengan tujuan untuk memahami perangkat lunak yang di harapkan oleh pengguna dan perangkat lunak terbatas. Analisis Kebutuhan ini diperoleh dengan wawancara dan observasi secara langsung.

b. Perancangan

Perancangan (design) dibuat untuk merancang use case diagram, activity diagram, ERD dan rancangan tampilan aplikasi warung kuliner.

a. Use Case Diagram

Perancangan ini menjelaskan bahwa semua hasil akhir yang berkaitan dengan aplikasi adalah tanggung jawab dari kasir. Gambaran dari Use Case Diagram ditunjukkan pada Gambar 2.

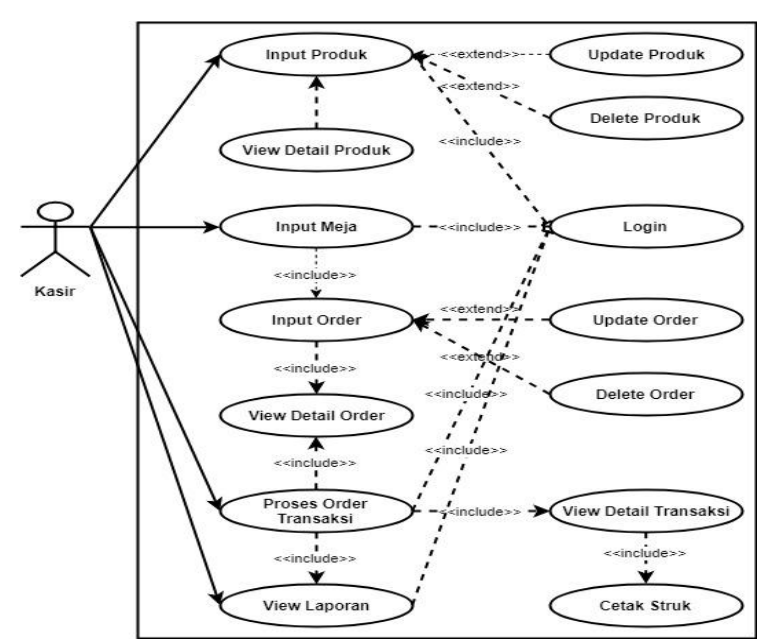

Gambar 2. Use Case Diagram 


\section{b. Activity Diagram}

Diagram ini sebagai gambaran aktivitas yang di jalankan sistem dalam aplikasi berbasis web, seperti proses penambahan order yang dilakukan oleh kasir sampai dengan transaksi serta pencetakan struk pembayaran. Ditunjukkan pada Gambar 3.

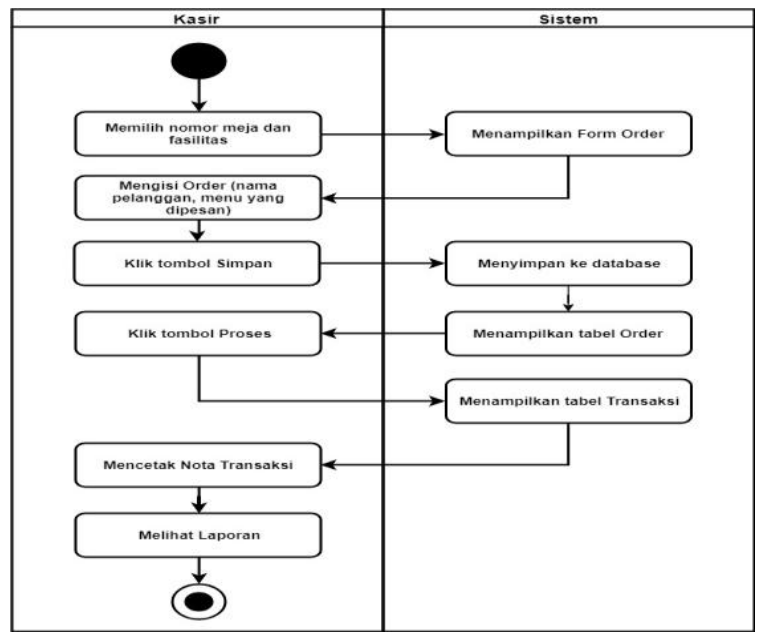

Gambar 3. Activity Diagram

\section{c. ERD (Entity Relationship Diagram)}

Penelitian ini membutuhkan sebuah database yang dibangun menggunakan software DBdesigner, kemudian diimplementasikan dalam Database. Database ini terdiri dari beberapa tabel yaitu tabel user, tabel meja pesan, tabel pelanggan, tabel produk, tabel transaksi, tabel detail transaksi, tabel order dan tabel detail order. Hubungan relasi antar tabel ditunjukkan pada Gambar 4.

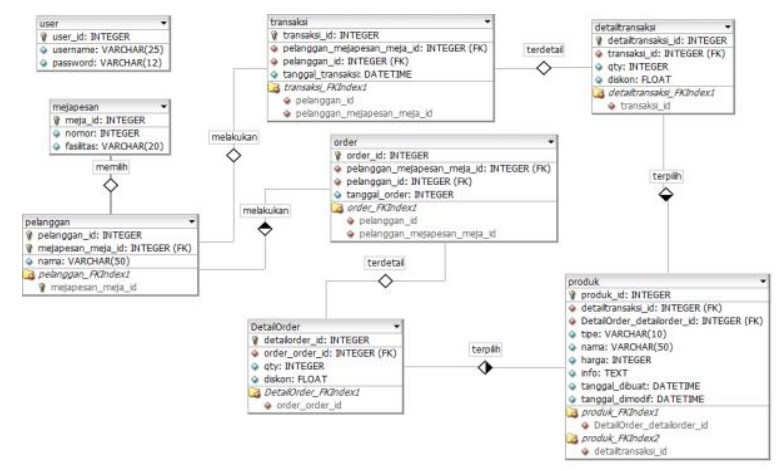

Gambar 4. ERD d. Rancangan Tampilan

Rancangan tampilan aplikasi berbasis web ini berguna sebagai Analisis bisnis serta efisiensi waktu luang untuk beberapa pengusaha UMKM (Usaha Mikro Kecil Menengah). Rancangan halaman utama dari Aplikasi Kasir terdiri dari Menu untuk memilih meja yang di pesan, Produk Populer dan Right Sidebar yang ditunjukkan pada Gambar 5. Tampilan dari langkah selanjutnya yaitu penambahan nama dan produk yang dipesan, ditunjukkan pada Gambar 6.

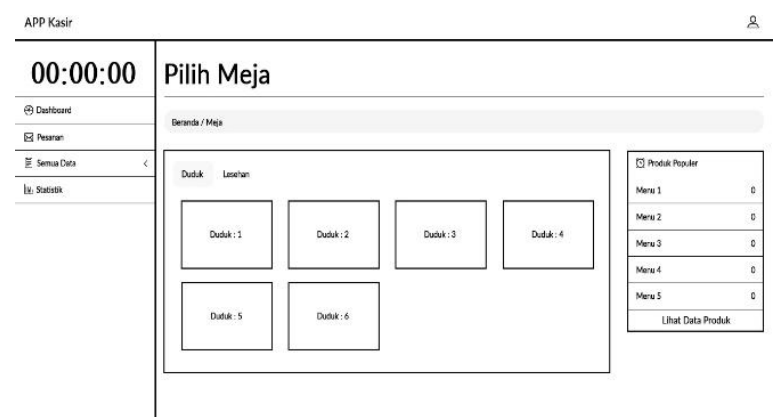

Gambar 5. Rancangan Memilih Meja

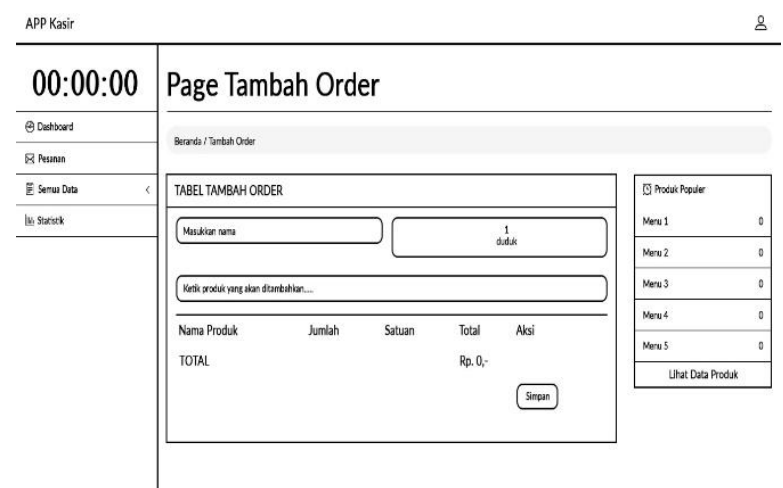

Gambar 6. Rancangan Tambah Order

c. Pengembangan

Pembuatan aplikasi ini menggunakan beberapa pendukung seperti Bootstrap sebagai tampilan aplikasi dan Python Django sebagai bahasa pemrograman.

d. Pengujian

Pengujian dari Sistem Informasi Kuliner ini menggunakan Metode black box yang lebih terfokus pada fungsionalitas sistem.

e. Implementasi

Sistem Informasi Kuliner ini dapat diimplementasikan dengan sebuah jaringan lokal misalnya menggunakan localhost. 
Sistem ini dapat dioperasikan tanpa adanya koneksi internet bahkan tidak harus terintegrasi dengan layanan hosting.

\section{HASIL DAN PEMBAHASAN}

Hasil dari sistem ini adalah suatu sistem yang mempunyai beberapa halaman untuk mempermudah sebuah warung kuliner dalam melakukan proses transaksi.

Kasir dapat menambah produk, memilih nomor meja yang dipilih pelanggan, menambah pelanggan disertai nama, produk yang dipesan serta pembayaran berupa nota. Menu yang telah ditambahkan dapat dilihat secara detail yang ditunjukkan pada Gambar 7.

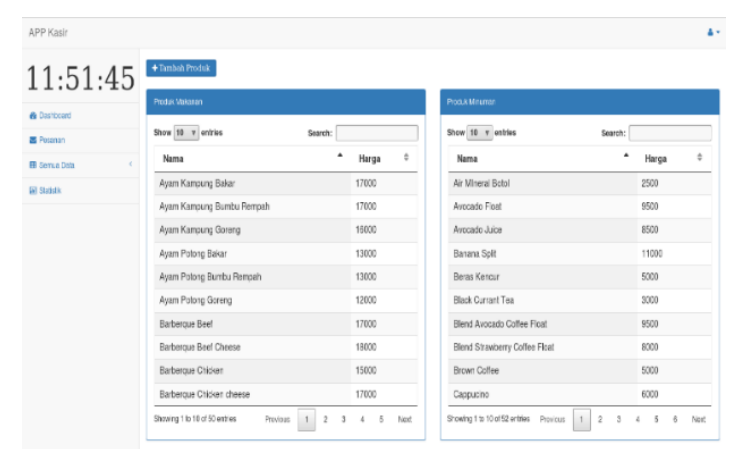

Gambar 7. Detail Menu

Pihak warung dapat menginputkan nomor meja serta posisi duduk atau lesehan yang telah dipilih oleh pelanggan. Ditunjukkan pada Gambar 8.

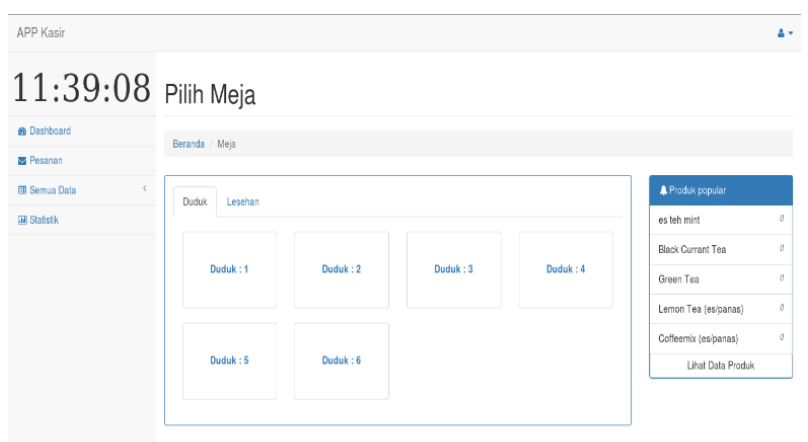

Gambar 8. Nomor Meja dan Posisi

Setelah memilih nomor meja, pihak warung menginputkan nama pelanggan, produk makanan dan minuman yang dipilih pelanggan beserta dengan jumlahnya. Sistem otomatis menampilkan harga produk, total harga per produk serta total harga transaksi secara keseluruhan. Ditunjukkan pada Gambar 9.

\section{1:40:05 Page Tambah Order}

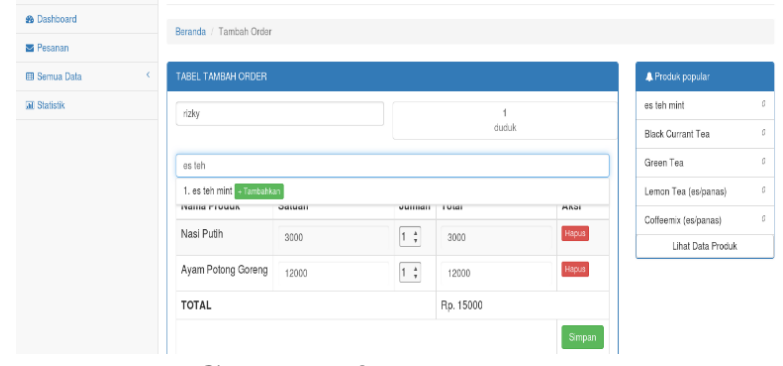

Gambar 9. Input Pesanan

Pesanan yang telah diinputkan dapat dilihat di tabel order berdasarkan dari beberapa pelanggan. Ditunjukkan pada Gambar 10.

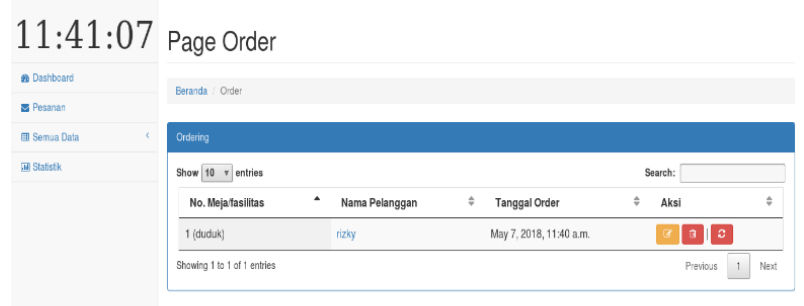

Gambar 10. Tabel Order

Pihak warung dapat melihat laporan transaksi dari pelanggan meliputi nama pelanggan, tanggal dan waktu pemesanan serta transaksi, dan total dari transaksi tersebut. Untuk mempermudah pihak warung, laporan dapat ditampilkan berdasarkan tanggal transaksi yang dipilih. Ditunjukkan pada Gambar 11.

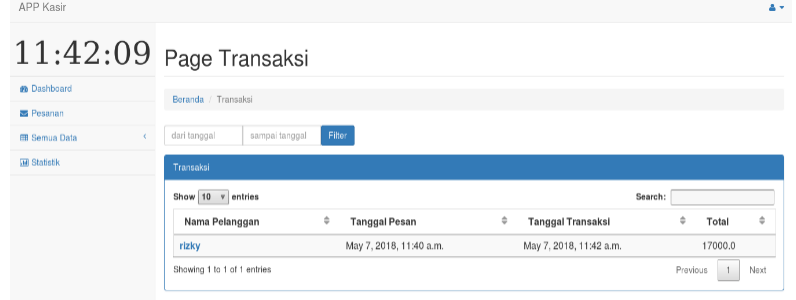

Gambar 11. Laporan Transaksi 
Sistem dapat menampilkan suatu grafik berdasarkan jumlah transaksi per hari serta per bulan. Ditunjukkan pada Gambar 12a dan 12b.

11:52:49 Page Statistik

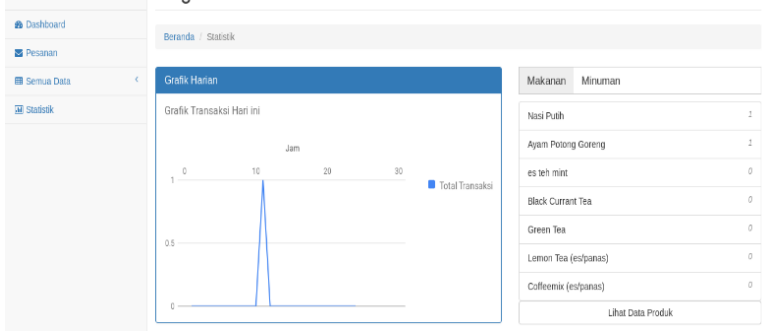

Gambar 12a. Grafik Transaksi

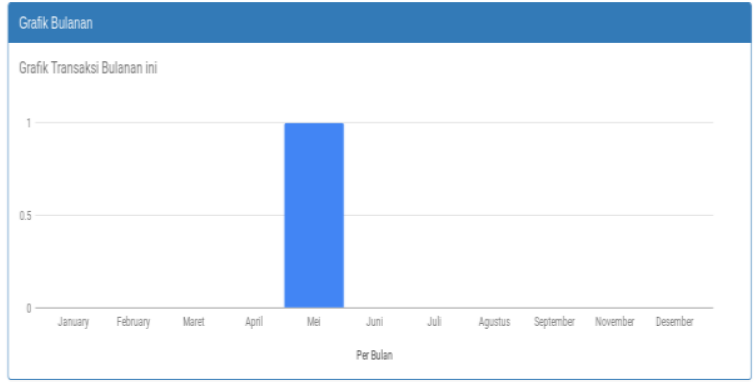

Gambar 12b. Grafik Transaksi

Sistem mencetak hasil transaksi dengan format PDF. Ditunjukkan pada Gambar 13.

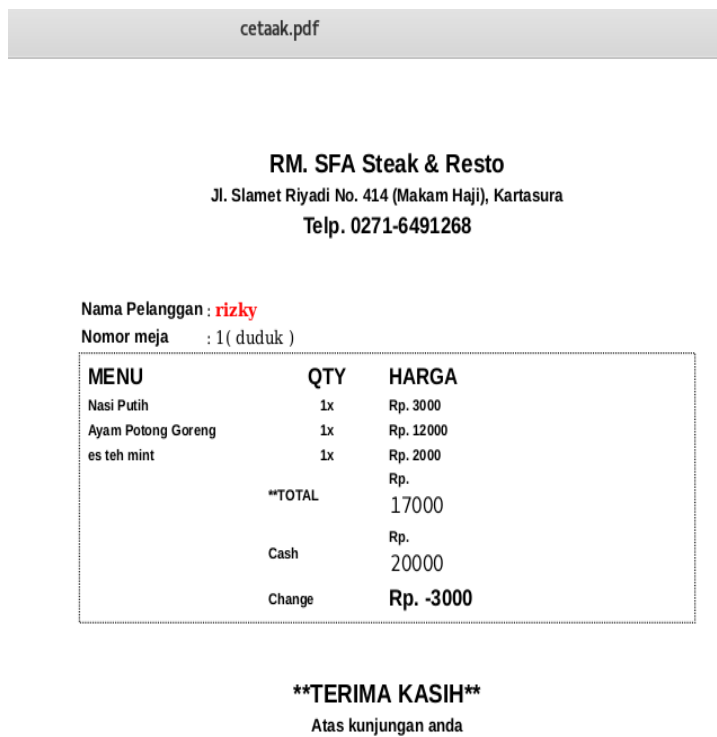

\section{Gambar 13. Nota Transaksi}

Pengujian sistem ini lebih berfokus pada fungsionalitasnya dan memastikan bahwa semua bagian telah diuji. Sistem ini diuji dengan Metode black box yang bertujuan untuk mengetahui apakah sistem yang dibuat sudah berjalan dengan baik atau belum. Pengujian ini ditunjukkan pada Tabel 1.

Tabel 1. Hasil Pengujian Metode Black Box

\begin{tabular}{|c|c|c|c|}
\hline $\begin{array}{l}\text { Fitur/ } \\
\text { Menu }\end{array}$ & Test Case & $\begin{array}{l}\text { Hasil yang } \\
\text { diharapkan }\end{array}$ & Hasil \\
\hline \multirow{2}{*}{$\begin{array}{l}\text { LOGI } \\
\mathrm{N}\end{array}$} & $\begin{array}{l}\text { User \& } \\
\text { Password } \\
\text { Benar }\end{array}$ & Masuk ke sistem & Valid \\
\hline & $\begin{array}{l}\text { User \& } \\
\text { Password } \\
\text { Salah }\end{array}$ & $\begin{array}{l}\text { Muncul pop window } \\
\text { gagal }\end{array}$ & Valid \\
\hline \multirow{4}{*}{$\begin{array}{l}\text { Pengo } \\
\text { lahan } \\
\text { Data } \\
\text { Produ } \\
\text { k }\end{array}$} & $\begin{array}{l}\text { Klik } \\
\text { Tombol } \\
\text { Tambah } \\
\text { Produk }\end{array}$ & $\begin{array}{l}\text { Menampilkan Form } \\
\text { untuk menambah } \\
\text { Produk }\end{array}$ & Valid \\
\hline & $\begin{array}{l}\text { Klik } \\
\text { Tombol } \\
\text { Data } \\
\text { Produk }\end{array}$ & $\begin{array}{l}\text { Menampilkan Data } \\
\text { Produk }\end{array}$ & Valid \\
\hline & $\begin{array}{l}\text { Klik } \\
\text { Tombol } \\
\text { Edit } \\
\text { Produk }\end{array}$ & $\begin{array}{l}\text { Menampilkan } \\
\text { halaman untuk } \\
\text { mengubah Data } \\
\text { Produk }\end{array}$ & Valid \\
\hline & $\begin{array}{l}\text { Klik } \\
\text { Tombol } \\
\text { Hapus } \\
\text { Produk }\end{array}$ & $\begin{array}{l}\text { Muncul Pop } \\
\text { Windows hapus dan } \\
\text { Data terhapus di tabel } \\
\text { produk }\end{array}$ & Valid \\
\hline \multirow{6}{*}{$\begin{array}{l}\text { Pengo } \\
\text { lahan } \\
\text { Data } \\
\text { Order }\end{array}$} & $\begin{array}{l}\text { Klik } \\
\text { Nomor } \\
\text { meja yang } \\
\text { dipilih }\end{array}$ & $\begin{array}{l}\text { Menampilkan } \\
\text { halaman untuk } \\
\text { menambah Order }\end{array}$ & Valid \\
\hline & $\begin{array}{l}\text { Klik } \\
\text { Tombol } \\
\text { Simpan } \\
\end{array}$ & $\begin{array}{l}\text { Menyimpan ke } \\
\text { database dan tampil } \\
\text { di system }\end{array}$ & Valid \\
\hline & $\begin{array}{l}\text { Klik } \\
\text { Tombol } \\
\text { Detail } \\
\text { Order }\end{array}$ & $\begin{array}{l}\text { Menampilkan Data } \\
\text { Order secara detail } \\
\text { berdasarkan } \\
\text { pelanggan }\end{array}$ & Valid \\
\hline & $\begin{array}{l}\text { Klik } \\
\text { Tombol } \\
\text { Edit data } \\
\text { Order } \\
\end{array}$ & $\begin{array}{l}\text { Menampilkan } \\
\text { halaman untuk } \\
\text { mengubah data Order }\end{array}$ & Valid \\
\hline & $\begin{array}{l}\text { Klik } \\
\text { Tombol } \\
\text { Hapus } \\
\text { Order } \\
\end{array}$ & $\begin{array}{l}\text { Muncul Pop windows } \\
\text { dan Data terhapus di } \\
\text { tabel Order }\end{array}$ & Valid \\
\hline & $\begin{array}{l}\text { Klik } \\
\text { Tombol } \\
\text { Proses }\end{array}$ & $\begin{array}{l}\text { Muncul Pop } \\
\text { Windows, data } \\
\text { Pindah di Data } \\
\text { Transaksi dan } \\
\text { terhapus dari Data } \\
\text { Order }\end{array}$ & Valid \\
\hline
\end{tabular}




\begin{tabular}{|l|l|l|l|}
\hline $\begin{array}{l}\text { Fitur/ } \\
\text { Menu }\end{array}$ & Test Case & $\begin{array}{l}\text { Hasil } \\
\text { diharapkan }\end{array}$ & Hasil \\
\hline $\begin{array}{l}\text { Data } \\
\text { Trans } \\
\text { aksi }\end{array}$ & $\begin{array}{l}\text { Tombol } \\
\text { Detail } \\
\text { Transaksi }\end{array}$ & $\begin{array}{l}\text { Kenampilkan data } \\
\text { transaksi berdasarkan } \\
\text { pelanggan }\end{array}$ & Valid \\
Tombol & $\begin{array}{l}\text { Muncul Pop view } \\
\text { PDF data hasil } \\
\text { Transaksi dan dapat di } \\
\text { Download/Cetak } \\
\text { secara langsung }\end{array}$ & Valid \\
\hline $\begin{array}{l}\text { Lapor } \\
\text { an } \\
\text { Hasil } \\
\text { Trans } \\
\text { aksi }\end{array}$ & $\begin{array}{l}\text { Klik } \\
\text { Tombol } \\
\text { Laporan/St } \\
\text { atistik }\end{array}$ & $\begin{array}{l}\text { Menampilkan hasil } \\
\text { laporan transaksi }\end{array}$ & Valid \\
\hline $\begin{array}{l}\text { Logou } \\
\text { t }\end{array}$ & $\begin{array}{l}\text { Klik } \\
\text { Tombol } \\
\text { Logout }\end{array}$ & $\begin{array}{l}\text { Berhasil keluar dari } \\
\text { sistem }\end{array}$ & Valid \\
\hline
\end{tabular}

Berdasarkan hasil pengujian Metode black box yang telah dilakukan menunjukkan bahwa sistem ini sudah berjalan dengan baik dari segi fungsionalitas dan tidak ditemukannya kesalahan dalam sistem. Sistem ini tidak menutup kemungkinan terjadi kesalahan di masa mendatang sehingga dibutuhkan waktu untuk menyempurnakan kembali sistem ini.

\section{PENUTUP}

Sistem Informasi Warung Kuliner yang telah dibuat diharapkan dapat membantu dan mempermudah sebuah warung dalam melakukan proses transaksi, serta tidak mengeluarkan biaya untuk mendapatkan sistem tersebut karena telah dibagikan secara gratis melalui Github https://github.com/rizkyarwn/ projectkasir. Dalam pengembangannya, kemungkinan sistem ini dapat terjadi beberapa kesalahan sehingga memerlukan adanya perawatan serta monitoring untuk perbaikan sistem. Sistem lebih baik jika dikembangkan dengan suatu data yang tampil berdasarkan jangka waktu yang ditentukan.

\section{DAFTAR PUSTAKA}

[1] Shraddha G. Malviya, N. (2016). A Review Paper on Smart Restaurant Ordering System. International Journal of Scientific \& Engineering Research, 7(2), 629-632.

[2] Nugroho, J. S., \& Djajalaksana, Y. M. (2015). Aplikasi Web Reservasi dan Penjualan untuk Restoran. Jurnal Sistem Informasi, 9(2), 127-147.

[3] Firdaus, I. dkk. (2014). Rancang Bangun E-Resto Menggunakan Web Services untuk Restoran Family di Kotamadya Surakarta. Jurnal Sainstech Politeknik Surakarta, 1(2).

[4] Deti, Leni K., Herry Mulyono. (2017). Analisis dan Perancangan Sistem Informasi Penjualan dan Pemesanan Plywood Berbasiskan Web pada PT. Kumpeh Karya Lestari Jambi. Jurnal Manajemen Sistem Informasi, 2(1). 